\title{
Finance Capital Launches an Assault on Chinese Real Estate
}

\section{Natacha Aveline-Dubach}

Translator. Elizabeth Guill

\section{Q OpenEdition \\ Journals}

\section{Electronic version}

URL: http://journals.openedition.org/chinaperspectives/6157

DOI: 10.4000/chinaperspectives.6157

ISSN: 1996-4617

Publisher

Centre d'étude français sur la Chine contemporaine

\section{Printed version}

Date of publication: 1 June 2013

Number of pages: 29-39

ISSN: 2070-3449

\section{Electronic reference}

Natacha Aveline-Dubach, «Finance Capital Launches an Assault on Chinese Real Estate », China Perspectives [Online], 2013/2 | 2013, Online since 01 June 2016, connection on 10 December 2020. URL : http://journals.openedition.org/chinaperspectives/6157; DOI : https://doi.org/10.4000/ chinaperspectives.6157 


\title{
Finance Capital Launches an
}

\section{Assault on Chinese Real Estate}

\author{
NATACHA AVELINE-DUBACH
}

\begin{abstract}
Over the past two decades, global market finance has taken root in China to seek property investment. This article examines the spatialities and anchorage methods of finance capital within Chinese national territory. It highlights the spatial and sectoral differences in the composition of property portfolios as a function of the return/risk coupling. These differences are exacerbated by a split in the geographical origin of the funds, which determines differentiated conditions of access to land and management of the investment time horizon of the assets portfolios. The penetration of finance capital into urban space tends to increase the fragmentation and functional specialisation of districts, a phenomenon fostered by entrepreneurial urban policies. As a result, urban projects are becoming standardised in terms of both design and program. They are increasingly governed by external references that favour the expansion of multinationals and transform lifestyles and consumer habits.
\end{abstract}

KEYWORDS: Property, real estate, financialisation, investment, private equity, REIT, securitisation, property development, urban development.

$\mathrm{O}$ ver the last two decades, property markets have undergone a process of "financialisation" brought about by the global expansion of market finance. This change is characteristic of the new regime of capital accumulation that emerged in the 1980s, establishing the predominance of finance over industry (1) and favouring the rise in power of institutional investors. ${ }^{(2)} \mathrm{A}$ crucial stage in this process was the deregulation of the financial markets, the effects of which proved spectacular in Asia, namely the explosion of a gigantic "property bubble" in Japan, followed by the triggering of the Asian crisis on the Thai property markets in 1997. (3) Up until now, China has been spared systemic crises, as its resilience in the face of the subprime mortgage debacle shows. Nonetheless, it has not escaped speculative mechanisms in the property market, or even bubbles, ${ }^{(4)}$ which encourage it to exercise caution in the face of the penetration of foreign financial capital. The penetration of such capital has admittedly been timid with regard to the deployment of multinationals in industry, but has been steadily increasing for the last ten years or so.

The stakes are very high indeed. Urbanisation has intensified in China, coastal megacities have expanded, and regional capitals have become giant cities. The latter will now have to provide the facilities needed to meet the needs of a rapidly growing middle-class that aspires to urban change. China therefore represents a true Eldorado for global financial capital. Not only does this country offer formidable potential for a diversification of investment, it also promises excellent performance supported by growth dynamics that contrast with the lethargy of the industrialised economies.

This article falls within the scope of recent research in the field of financial geography that seeks to shed light on several distinctive aspects of financialised investment channels. Upstream of the channel, research has focused on the discriminatory nature of the risk-return coupling and time horizon in the spatial and sectoral strategies of investment funds. ${ }^{(5)}$ Downstream of the channel, the accent is on the role of mediator assumed by certain local urban operators in the anchorage of transnational capital. (6) Basing our observations on semi-directed interviews conducted with property operators in Hong Kong and Guangzhou, supplemented by exploiting the plen- tiful "grey literature" taken from the official sites of these companies, I show that differences in the investment strategies of the funds are accentuated by a split in the geographical origin of the sponsor groups. I also take account of the role of public policies in the full-scale urban restructuring that foreign financial investment allows as well as of the many changes resulting from this in urban life.

\section{Adaptation of the urban context to the requirements of finance capital}

The penetration of finance capital into the property sector is a response to the need felt by institutional investors, notably the pension funds of in-

1. André Orléan, Le pouvoir de la finance (The power of finance), Paris, Odile Jacob, 1999; Robert Boyer, "Is a Finance-led Growth Regime a Viable Alternative to Fordism? A Preleminary Analysis," Economy and Society, Vol. 29, No. 1, 2000, pp. 111-145.

2. Michel Aglietta, "New Trends in Corporate Governance: The Prominent Role of the Long Run Investor," Competition and Change, Vol. 12, No. 2, 2008, pp. 203-222.

3. Koichi Mera, Bertrand Renaud (eds.), Asia's Financial Crisis and the Role of Real Estate, New York, M.E. Sharpe, 2000. Natacha Aveline, Ling-Hin Li (eds.), Property Markets and Land Policies in NorthEast Asia, Hong Kong/Tokyo, Centre for Real Estate and Urban Economics/Maison Franco-Japonaise, 2004. Cedric D. J. Pugh, Alireza Dehesh, "The Internationalization of Post-1980 Property Cycles and the Japanese 'Bubble' Economy, 1986-96," International Journal of Urban and Regional Research, Vol. 23, No. 1, 1999, pp. 147-164.

4. Eddie C.M. Hui, Yue Shen, "Housing Price Bubbles in Hong Kong, Beijing and Shanghai: A Comparative Study," The Journal of Real Estate Finance and Economics, Vol. 33, No. 4, 2006, pp. $299-327$.

5. I would mention in particular the work of the following authors: Thierry Theurillat, José Corpataux, Olivier Crevoisier, "Property Sector Financialisation:The Case of Swiss Pension Funds (1992-2005)," European Planning Studies, Vol. 18, No. 2, 2010, pp. 189-212; Ludovic Halbert and Louise David, "Logiques financiers globales et fabrique de la ville" (Global financial logic and construction of the city), in Pierre Jacquet, Rajendra Pachauri, Laurence Tubiana, (eds.), Regards sur la Terre:Villes, changer de trajectoire (Earth watch:Towns, changing trajectory), Presses de Sciences Po, Paris, 2010, pp. 91108; Sabina Uffer, "What Is the Nature of Institutional Investors in Comparison with State-owned Housing Companies?", mimeo, paper presented at the AAG New York, 24-28 February 2011, 18 pp.

6. Thierry Theurillat "La ville négociée, entre financiarisation et durabilité" (The negotiated city, between financialisation and durability), Géographie, Économie et Société, Vol. 13, No. 3, 2011, pp. 225-254; Rodrigo Cattaeno "La fabrique de la ville: promoteurs immobiliers et financiarisation de la filière du logement à Santiago du Chili" (The making of the city: Property developers and financialisation of the housing sector in Santiago de Chile), doctoral thesis, University Paris 8, 7 December, 2012, mimeo, 529 pp. 
dustrialised countries, to diversify their investments to cope with the increased demand for savings and retirement services emanating from ageing societies. ${ }^{(7)}$ They generally allocate between 5 and $10 \%$ of their capital to property investment. ${ }^{(8)}$ This presents two main advantages: on the one hand, its performance is often only weakly correlated with that of the other categories of assets, which limits the overall risk to which institutional investors expose themselves in their portfolios, and on the other, it offers attractive return/risk couplings, notably in Asia. ${ }^{(9)}$ However, the integration of property into finance is not automatic. It requires property rights to be transformed into securities, listed or not, and exchangeable on the financial market. This operation removes the constraint of illiquidity that is a characteristic of property with its high "entry cost" (initial high investment, high taxation, and various expenses), fragmented markets, opacity of information, and long transaction times. The integration of property into finance implies the creation of institutional systems to cover the entire chain of operations involved in foreign investment, bringing global and local spheres into contact. How are these networks of players organised, and what channels do they develop to make Chinese property investment accessible to global finance capital?

Academic literature provides little information on this point. In the field of financial economics, the few existing research projects relating to property investment in China are angled exclusively from the point of view of the institutional investor, giving an account of the added-value offered by this category of asset in the management of a portfolio ${ }^{(10)}$ or the regulatory obstacles that hinder the creation of listed funds. ${ }^{(11)}$

Urban geography seems to be the discipline that sheds most light on the matter. Although research in this field does not explore the financialisation of property in itself, it takes the context into which it is inserted and examines the structural impact of property investment in the biggest Chinese cities.

As we know, China introduced a market of limited land rights for foreign companies in 1979. This practice was regularised by an amendment to the Constitution in 1988, generating a dual land market where market mechanisms coexist alongside an administered segment reserved for the public sector. ${ }^{12)}$ Wu notes the persistence of administrative channels in the attribution of land, an observation he links to the theory of the "persistence of power" characteristic of economies in transition. ${ }^{(13)}$ A 2009 inventory of the various channels by which land may be accessed confirms the abundance of administrative channels within a highly fragmented land market. (14) With regard to the sale of land rights, the regulations stipulate three possibilities: negotiation, adjudication, and auction. Local authorities favour the least transparent formula, negotiation, thereby perpetuating endemic corruption. From 2002 on, the government tried to advance market mechanisms by urging local authorities to practice the other two methods, ${ }^{(15)}$ but it cannot easily impose constraints after reducing grants to local authorities to a bare minimum. This strong institutional embedding of land constitutes a major obstacle to foreign intervention on the Chinese property markets. Only operators with guanxi, or failing that, who can fall back on partnerships with Chinese firms, can hope to have direct access to land resources. It takes a long time to build up guanxi, giving an advantage to operators from Hong Kong, Macao, Singapore, and Taiwan, some of whom were born on the mainland. ${ }^{(16)}$

Foreign capital only became interested in Chinese property from the 1990s, after a decade devoted to industrial investment, in particular in the Special Economic Zones. It initially concentrated on the largest cities, Shanghai, Beijing, and Guangzhou, ${ }^{(17)}$ before moving on to other large cities, accompanying the migration of industrial capital to the country's interior regions. This capital has a very strong influence on the urban sphere in China. Firstly, foreign investment allows local authorities to finance their infrastructure expenses with income from the sale of land rights, ${ }^{(18)}$ leading to a virtuous circle by which the proliferation of infrastructure then increases investment opportunities. ${ }^{(19)}$ All cities are not in the same situation, however. Guangzhou and Shanghai, for example, are better adapted to negotiation over the price of land rights than other cities such as Tianjin. (20)

Another effect has been to stimulate the diversification of the urban structure. In the past, Chinese cities followed a principle of cellular organisation based on danwei (work units), characterised by a highly diversified use of the land with a low density of buildings and many industrial installations in urban areas (factories and warehouses). Foreign capital has guided the "invisible hand" of the market by privileging sites in central districts, accelerating the migration of unprofitable activities towards the outskirts. ${ }^{(21)}$ Land use plans have adapted to this new situation, significantly raising floor area ratios. ${ }^{(22)}$ This has led to the functional specialisation of districts, distributing the value of the property in a more coherent and legible manner, once again to the great benefit of foreign investment, which has consequently stimulated the emergence of a luxury residential market segment. Originally considered a niche market intended above all for expatriates, luxury housing developed with the gradually increasing wealth of the Chinese middle classes, becoming a highly lucrative sub-sector all the less risky since the clientele was solvent. ${ }^{(23)}$

7. Gordon Clark, Pension Fund Capitalism, Oxford, Oxford University Press, 2000, and Gordon Clark, European Pensions and Global Finance, Oxford, Oxford University Press, 2003.

8. Morag Torrance, "Forging Glocal Governance? Urban Infrastructures as Networked Financial Products," International Journal of Urban and Regional Research, Vol. 32, 2008, pp. 1-21.

9. Joseph Ooi, Graham Newell, Sing Tien Foo, "The Growth of REITs Markets in Asia," Journal of Real Estate Literature, Vol. 14, No. 2, 2006, pp. 203-222.

10. Graham Newell, Woo Peng, "The Impact of the Global Financial Crisis on A-REIT Risk," Pacific Rim Property Research Journal, Vol. 15, 2009, pp. 453-470.

11. Michael Quek, Seow Eng Ong, "Securitising China Real Estate: A Tale of Two China-centric REITs," Journal of Property Investment and Finance, Vol. 26, 2008, pp. 247-273.

12. Xing Quan Zhang, "Urban Land Reform in China," Land Use Policy, Vol. 3, No. 14, 1997, pp. 187199 .

13. Fulong Wu, "China's Changing Urban Governance in the Transition Towards a More Market-oriented Economy," Urban Studies, Vol. 39, No. 7, 2002, pp. 1071-1093.

14. Jiang Xu, Anthony Gar-On Yeh, Fulong Wu, "Land Commodification: New Land Development and Politics in China since the late 1990s Solutions," International Journal of Urban and Regional Research, Vol. 33, No. 4, 2009, pp. 890-913.

15. Jiang Xu, J.Anthony Gar-On Yeh, "Decoding Urban Land Governance: State Reconstruction in Contemporary Chinese Cities," Urban Studies, Vol. 46, No. 3, 2009, pp. 559-581.

16. This is the case in particular for several founders of Hong Kong property groups who arrived from mainland China in the pre-war period (Alice Poon, Land and the Ruling Class in Hong Kong, Enrich Professional publishing, 2nd edition, Singapore, 2010).

17. Zhigang Li, Fulong Wu, "Socioeconomic Transformations in Shanghai (1990-2000): Policy Impacts in Clobal-National-Local Contexts," Cities, Vol. 23, No. 4, 2006, pp. 250-268.

18. Jiang Xu, Anthony Gar-On Yeh, "Decoding Urban Land Governance: State Reconstruction in Contemporary Chinese Cities," Urban Studies, Vol. 46, No. 3, 2009, pp. 559-581. Guangzhong Cao, Changchun Feng, Ran Tao, "Local 'Land Finance' in China's Urban Expansion: Challenges and Solutions," China \& World Economy, Vol. 16, No. 2, 2008, pp. 19-30.

19. Anthony Gar-On Yeh, "Dual Land Market and Internal Spatial Structure of Chinese Cities," in Laurence Ma and Fulong Wu (eds.), Restructuring the Chinese Cities: Changing Society, Economy and Space, Routledge, Abingdon, 2005, pp. 59-79.

20. David Dowall, "Establishing Urban Land Markets in the People's Republic of China," Journal of the American Planning Association, Vol. 59, No. 2, 2007, pp. 182-192.

21. Fulong Wu, "The Transformation of Urban Space in Chinese Transitional Economy: With Special Reference to Shanghai," in John Logan (ed.), The New Chinese City: Clobalization and Market Reform, Oxford, Blackwell Publishers, 2002, pp. 154-166.

22. The floor area ratio is a ratio of authorised building volume on a given land parcel. For example, a $\operatorname{COS}$ of 1 authorises 100 square metres of net floor area to be built on land with a surface area of 100 square metres.

23. Fulong Wu, "China's Recent Urban Development in the Process of Land and Housing Marketisation and Economic Globalisation," Habitat International, Vol. 25, 2001, pp. 273-289. 
With spatial differentiation comes the means to practice a more localised form of urban governance. In the newly created districts - free zones, technological parks, and commercial complexes - local authorities can implement targeted policies to attract mainly foreign investment or even experiment by drawing on the regulatory and fiscal toolboxes. ${ }^{(24)}$ The capacity of foreign capital to mobilise very large sums in a very short time makes it particularly attractive for the realisation of large-scale projects. ${ }^{(25)}$ Local authorities encourage in particular the construction of big business complexes, whose tax revenues (tax on added-value and profits) now constitute the main component of their budgetary resources. (26) Their strategy consists of limiting the land supply in this sector - as in the residential sector, moreover - in order to maximise income from land rents. On the other hand, in the industrial sector, they concede land at far lower values since the performances of municipal officers are judged on their ability to increase the local Gross Domestic Product (GDP). (27)

Several authors have underlined the significant impact these major flagship operations financed by foreign investors are having. With their prestigious architectural design, most often the work of well-known Western architects, these big projects appear to be the bearers of a new urban order. ${ }^{(28)}$ They introduce new city lifestyles, in particular in residential and retail districts (air-conditioned shopping malls where strolling about has become a form of entertainment), and these tend to prevail as models for ordinary urban production. The formal and cultural standardisation they produce constitutes an additional factor for attracting global finance capital, since investors' familiarity with programmed urban objects allows them to evaluate return/risk profiles more easily. Local authorities therefore spare no effort to amass vast supplies of land within central and peri-central areas. Operating in sites with high potential, they gradually gain control of the land through "land banks" within complex, diversely regulated markets. According to Zhu, these "growth coalitions" between local authorities and foreign operators are being formed to the detriment not only of users but also of the central government. They prevent the transition towards a competitive land market and encourage construction at the risk of overproduction of property in certain localities. ${ }^{(29)}$

The state is well aware of the social and environmental risks these entrepreneurial practices on the part of the local authorities carry and which place the very survival of the regime on the line. Several solutions have been tried, such as the introduction of a land tax in several large cities, the introduction of an obligatory quota of agricultural land to be preserved, and the extension of the ecocities model to 200 sites. But these initiatives have so far proved ineffective in creating social and environmental durability. ${ }^{(30)}$

\section{Hierarchisation of Chinese land by property consultancies}

Foreign investors need a thorough knowledge of the Chinese property market in order to understand risk, evaluate performance, and choose between the innumerable opportunities that present themselves. International property consultancies have therefore been present in China since the late 1980 s to offer a local staging-post. The market is shared mainly between five companies: Savills, DTZ, JLL, Colliers, and CBRE. (31) The first two have been in China the longest and have the greatest number of branches. Savills set up in China in the late 1980s, followed by DTZ in 1993. These two companies are now present in 12 and 16 cities respectively. The current chief executive of Hong Kong, C.Y. Leung, was one of the great artisans of the development in China of DTZ, of which he was a director until 2011. ${ }^{(32)}$ As for the three other consultancies, although they have less extensive cover in China, they are nonetheless very important players at the international level, which allows them to offer their clients - as far as CBRE and JLL are concerned, at least - investment opportunities in addition to their basic services.

These "big five" are essential facilitators for any attempt at penetration into the Chinese property market. They play a key role in the anchoring of foreign capital through the setting up of partnerships with Chinese companies, often in the contractual form of a joint venture (JV) giving foreign investors access to the land and capital of their Chinese partners. These consultancies originally dealt with demand from foreign clients, but then found themselves offering an increasing number of services to local companies. Their Chinese clients are state-run companies listed on the Shanghai, Shenzhen, or most often Hong Kong stock exchanges, and are obliged to publicise the value of their assets. International consultancies value their property, which enables them to refine their knowledge of local property markets through the maintenance of databases that are constantly being added to and regularly updated. These close links with Chinese clients place them in a privileged position for identifying opportunities and for drawing on this pool for the creation of partnerships with foreign operators. Certain branches have big valuation departments. One such case is the Guangzhou DTZ branch, which carries out a hundred valuations a day, a task that occupies no fewer than 30 employees.

At first, training Chinese salespeople to work for these companies was no small matter. They had to be inculcated with Western "codes of good conduct," i.e., they were no longer allowed to charge for putting people in contact with one another and had to respect contracts, not to mention the indispensable upgrading of their technical skills. In the beginning, training courses in Guangdong Province were organised by DTZ in partnership with the Hong Kong Chamber of Commerce, at the initiative of C.Y. Leung. (33) Training was then taken over by the universities, both in Hong Kong (Hong Kong University, Hong Kong Polytechnic University) and on the mainland (Tsinghua and Beida universities in Beijing, and Zhejiang University in Hangzhou).

Thanks to their monitoring of the local property markets, consultancies are key providers of information in a sector suffering from a high degree of opacity. Their branches are concentrated in six cities close to the coast (Shanghai, Hangzhou, Beijing, Tianjin, Guangzhou, and Shenzhen) and two

24. Fulong $\mathrm{Wu}, 2002$, op. cit.

25. Fulong Wu, "The Global and Local Dimensions of Place-making: Remaking Shanghai as a World City," Urban Studies, Vol. 37, No. 8, 2000, pp. 1359-1377.

26. Fulong Wu, "The Transformation of Urban Space in Chinese Transitional Economy: With Special Reference to Shanghai," op. cit., pp. 154-166.

27. Guangzhong Cao, Changchun Feng, Ran Tao, 2008, op. cit., pp. 19-30.

28. Fulong Wu, "Globalization, Place Promotion, and Urban Development in Shanghai," Journal of Urban Affairs, Vol. 25, No. 1, 2003, pp. 55-78.

29. Jieming Zhu, "Local Growth Coalitions: The Context and Implications of China's Gradualist Urban Land Reforms," International Journal of Urban and Regional Research, Vol. 23, No. 3, 1999, pp. 534-548.

30. Chien Shiuh-Shen: "Chinese Eco-Cities, a Perspective of Land-Speculation-Oriented Local Entrepreneurialism," China Information, to be published in 2013.

31. JLL: Jones Lang Lassalle; CBRE: CB Richard Ellis.

32. C.Y. Leung was already operating in China, where he was director of a company called C.Y. Leung \& Co. In 2000, his company merged with DTZ.

33. Liu Mei Hong Amy, David Zweig, "Hong Kong's Contribution to Mainland China's Property Sector, Helping to Turn Shanghai into a World City," Asia Survey, Vol. 51, No. 4, 2011, pp. 739-768. 


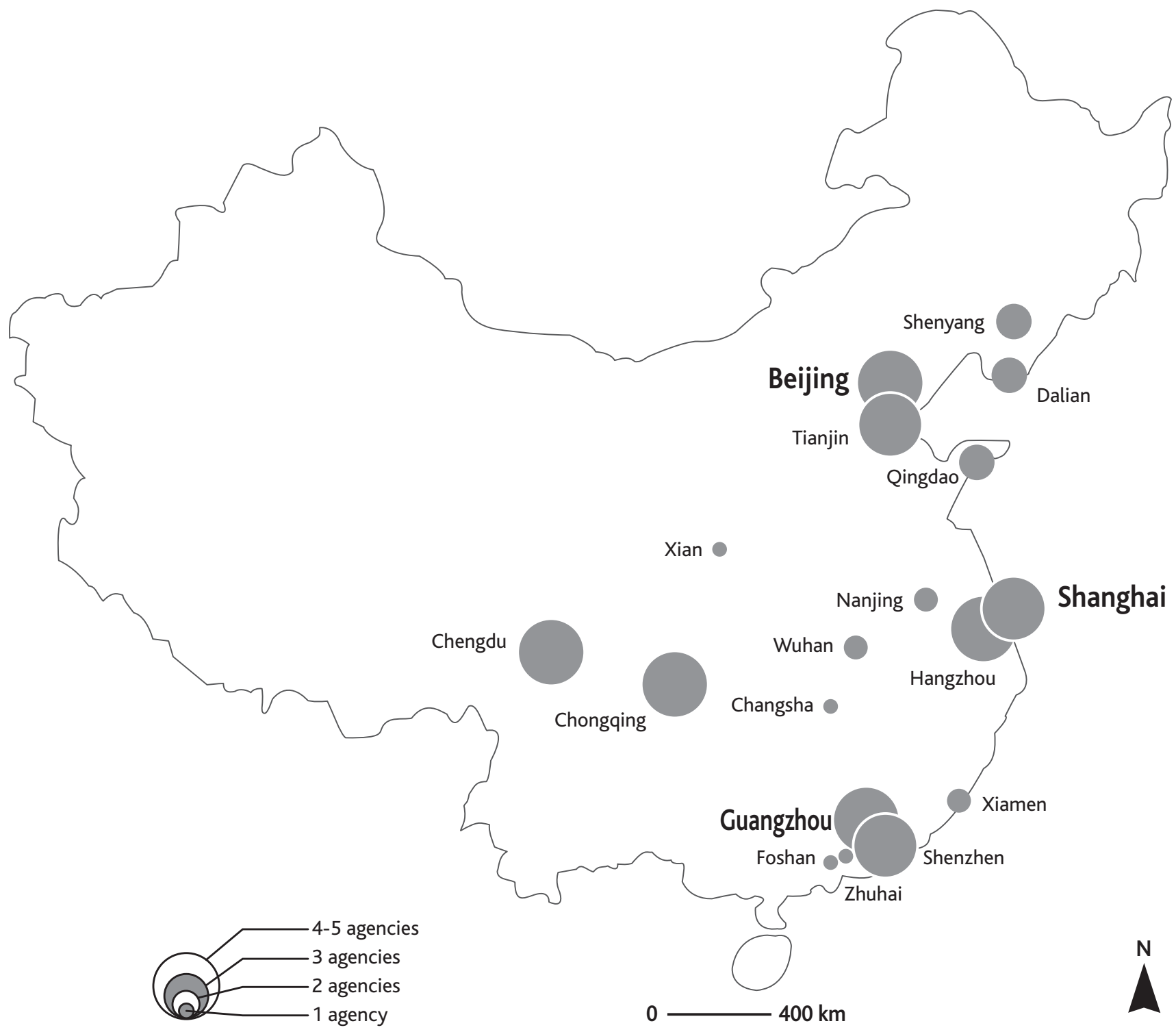

in the interior (Chongqing and Chengdu), but they have recently expanded to secondary metropolises such as Dalian, Shenyang, and Qingdao (Map 1). This network serves as the backbone for a deployment strategy in Chinese territory that is redrawing the investment map.

In 2007, JLL, which produces reference documents based on a series of economic, demographic, and property indicators, ${ }^{(34)}$ drew a map of the 30 Chinese cities considered to be "urban stars," (35) from which emerged three major centres along the coast around cities said to belong to "Category 1." These were Beijing, Shanghai, and Guangzhou. A recent update, enhanced by a further 20 cities (map 2), shows the reinforcement of the previous centres along with the arrival of Shenzhen in the first category, the emergence of a new axis in the north-east from Shenyang to Harbin, and the rapid rise of the big regional capitals of the interior (Chengdu, Chongqing, and Wuhan) on their way to joining the top-ranking cities. Other cities in the interior such as Xi'an, Changsha, Zhengzhou, and Ji'nan have been noted as "booming" (Category 2), and the network is completed by cities in the $3^{\text {rd }}$ and $4^{\text {th }}$ category designated as "emerging"; Haikou, Kun- ming, Nanjing, and Guiyang to the south and Lanzhou and Hohhot in the north. Unsurprisingly, the whole of the western part of the country remained untouched, with the exception of Urumai, a town that appeared on the investors' radar in 2009.(36)

The orientations of the 12th Five-Year Plan (2011-2015) were a strong determining factor in the hierarchisation of this urban network, whose economic weight has been estimated by JLL at US\$ 2.9 trillion - or the equivalent of the GDP of Germany - and its share of world production at $12 \%$ in the course of the next decade. The spatial hierarchy defined by JLL allows investors to identify urban profiles more easily and thus select the most suitable property products. ${ }^{(37)}$

34. These 50 cities were selected from a sample of 280 cities and hierarchised by means of a statistical analysis that took into account local economic production (nominal value of the GDP, growth rate, GDP/per capita), the population, disposable income, amount of bank deposits, income from retail sales, DFI, gross fixed capital formation, and the political status of the city.

35. Jones Lang LaSalle, "China 30, China Rising Urban Stars," 2007.

36. JLL, "China 50, China Rising Urban Stars, Fifty Real Estate Markets that Matter," 2012.

37. The description of the categories of cities that follows comes from JLL's document "China 50." 
Category 1 consists of the "core cities," grouping together Beijing, Shanghai, Guangzhou, and Shenzhen. It represents the most liquid and transparent of the country's property markets, characterised by a very outward-looking economy, a concentration of big companies and high-quality property stock. Although foreign property operators do not refuse to invest in it, this category, considered mature, is of secondary interest at a time when opportunities are available in the emerging cities, and especially now that the land offer has reached saturation point. Nonetheless, the rarity of areas where investment is possible presents the advantage of stabilising the returns on property held by investment funds in these urban areas. In particular, Beijing is in a strong position at the national level with regard to the estimated growth of income from retail sales over the next four years. ${ }^{(38)}$

On the other hand, the nine cities or "transitional cities" in Category 1.5, which include the main economic centres in the northeast and central regions as well as the cities included in cluster city networks, are those that present a major attraction for investors. They have benefited from the state's industrial policies and their transport infrastructures have been extensively developed, stimulating the growth of direct foreign investment (DFI). Their diversified industrial base has enabled property development in all sectors. Five cities in particular emerge from this group: in first place is Chengdu, a large centre in the western provinces and anchored in what is historically the country's most fertile province, Sichuan. With strong growth and a centuries-old historic heritage, it is a city that is particularly attractive to multinationals, to whom the local authorities extend their warmest welcome. Chinese companies also develop quickly there, however, greatly increasing the demand for grade A property. The property markets of Shenyang and Chongqing have also been stimulated by the development of the big technological zones (an eco-industrial energy park and biotechnology industries, respectively) provided for in the $12^{\text {th }}$ Five-Year Plan. Moreover, Chongqing and Tianjin benefit from city-region status, ${ }^{(39)}$ exercising their authority over a very extensive region, which makes investment easier. As for Hangzhou, this metropolis currently holds the national record for per capita consumption as a result of a concentration of prestigious shopping facilities near its celebrated lake that attract both tourists and wealthy residents from surrounding areas. ${ }^{(40)}$

In Category 2, consisting of what are known as "growth cities," are ten cities that all have strong international connections and a high level of per capita income. Some are the provincial capitals of the Chinese interior (Xi'an, Changsha, Zhengzhou, and ji'nan), others are ports (Qingdao, Ningbo, and Xiamen), whilst a third group are part of the big coastal conurbations (Hefei, Wuxi, and Dongguan). Their high demographic potential (between 5 and 8 million inhabitants for the most part) generates demand in widely varied sectors of the property market, notably for grade $A$ offices and luxury shopping malls. To the cities of the interior may be added a very high demand for modern logistics facilities linked to the migration of the manufacturing sector in search of lower salaries in western areas.

The "emerging" cities in Category 3 present a similar profile to those of the preceding group, with the provincial capitals of the interior and coastal cities. Since they can be expected to experience higher living standards as a middle class develops, they are already the target of aggressive retail and hotel installation strategies that bring property investment in their wake.

Lastly, the "early adopter cities" most often have between 2 and 4 million inhabitants, ${ }^{(41)}$ and are identified as being likely to join the third category in the near future. Most are part of conurbations (in particular the Yangtze and Pearl River deltas), often near the coast, but some are regional centres such as Guiyang, Lanzhou, and Urumqi. Foreign pioneer companies position themselves here to benefit from the advantages of being a precursor, mainly in retail, but the demand for property comes mostly from Chinese companies. Contrary to categories 2 and 3, where great efforts have been made to increase the transparency of the property markets, the "early adopter cities" are characterised by a high degree of opacity. Investing there is therefore more risky, but the capital gain on the land is potentially more advantageous.

Over the next decade, this "China 50" network will concentrate on property investment in the upper segments, the preferred target of financial capital. In 2011, grade A corporate property stock stood at only 23 million square metres in this urban group, that is to say, equivalent to that of an American city such as New York. ${ }^{(42)}$ According to JLL estimates, this stock is expected to expand by some 30 million square metres over the next decade. The demand in other sectors is seeing even faster development. In supermarket outlets, consumer habits will be radically altered by the rising living standards of the middle classes. The "China 50" network has a market of 370 million consumers, including 260 million city-dwellers. Amongst the latter, 20\% now have an income of 30,000 yuan (i.e., 3,700 euros at the current exchange rate). However, their number is expected to double over the course of the next three years, whilst the median income per household will exceed 50,000 yuan. This development is a strong driving force for the big commercial complexes, where foreign investment is concentrated to the detriment of the big traditional shops run by local tradespeople. Unlike corporate property that needs to be centrally located, supermarkets can operate within in a vast perimeter that extends to the towns in the lower categories, which according to JLL represent a potential for construction of 80 million square metres in the next decade (that is to say, double the property stock in this sector in 2011).

Retail growth - in particular of e-commerce - is a motor for the logistics sector, which will be called upon to expand rapidly under the effect of the development of the transport infrastructure accompanying the expansion of business activities westwards. However, it is quite clear that logistics facilities are suffering from under-development. Quality stock only amounts to 13 million square metres within the "China 50" network, the equivalent of all the warehouses in Boston in the United States. What is more, it is concentrated in the country's two largest conurbations, the Pearl River Delta and the Shanghai agglomeration. Wonderful investment potential is therefore present in the interior of China, beginning with big regional centres such as Chengdu and Chongqing. Yet this sector comes up against a series of obstacles: high land values, administrative constraints, and lack of interest on the part of the local authorities, who favour more prestigious uses that bring larger fiscal revenues. Close contacts with Chinese operators and local authorities therefore play a vital role in this respect.

It should be noted that residential property, which was very promising in recent years, has ceased to be an object of interest for finance capital. The Chinese authorities have tightened up on credit and have imposed highly

38. DTZ, "High-end retail investment, ranking the opportunities," 23 May 2011, p. 9.

39. Four big Chinese cities have this status: Beijing, Shanghai, Chongqing, and Tianjin.

40. DTZ, "Research, Money into Property, Asia Pacific 2011, Engine of World Growth," 24 May 2011, pp. 16.

41. Some, such as Quanzhou, have fewer inhabitants $(400,000)$, whilst others, such as Luoyang, are much bigger ( 6 million inhabitants).

42. According to JLL's "Office Statistics New York" data, this city has 248.5 million square feet, or 23 million square metres of grade $\mathrm{A}$ stock. 




Source: Jones Lang LaSalle, "China50," 2012

restrictive regulations on the acquisition of second homes, at a risk of causing many small local development companies to go bankrupt. Therefore, all that remains are niches such as serviced apartments, but these properties are more closely related to hospitality than residential accommodation. With the impending acceleration of the ageing of the population, a new niche market might nevertheless develop in the form of residential accommodation for the elderly, in particular in the tropical regions of the south (the island of Hainan), which are already attracting retirees. ${ }^{(43)}$

\section{The opportunistic funds of the pioneer front}

Once the potential of the big Chinese cities in the various property segments has been evaluated, finance capital can be deployed towards China through various channels. It is a movement that is nonetheless very recent. Although indirect investment - through investment funds - in Chinese property appeared in the late 1990s, it has only really taken off since 2003. Its progress comes after a long and difficult period of direct investment by foreign operators. (44)

Hong Kong property developers were the first to get a foothold in mainland China towards the end of the 1980s, initially crossing the frontier to Guangdong. Urged by the Chinese authorities to penetrate further into their territory, several conglomerates (New World, Henderson Land, and Sun Hung Kai) dared to build in the biggest Chinese cities, but without great success until the late 1990s. ${ }^{(45)}$ These efforts were nonetheless transformed into lucrative social capital (guanxi with the authorities) and into abundant land reserves in Category 2 cities, advantages that are now proving primor-

43. Urban Land Institute, "China Cities Survey," 2011.

44. The direct property market corresponds to traditional investment in the form of purchases of property requiring large amounts of money. It is distinct from the indirect property market, where access is through the acquisition of shares (in property companies or listed funds) or in the form of a stake in unlisted funds holding portfolios of property debt or properties.

45. Liu and Zweig, 2011, op. cit. 
dial. (46) The strategy of the Hong Kong developers has been to position themselves in the upper segments of the commercial and corporate property market. In this way, they avoid competition with local developers and can display their know-how in the construction of large urban features that serve to mark their territory, whether these be skyscrapers or prestigious shopping malls. Without their contribution to the construction of property stock that meets international standards in Shanghai, the city would not have been able to achieve its current status, an ascension that was made, moreover, to the detriment of Hong Kong. ${ }^{(47)}$ As we will see later, groups from Singapore have also made a remarkable entry into the Chinese property market, followed more recently by the Australians. However, the Hong Kong groups are far more numerous and have been present for much longer, which strengthens their privileged position in the sector.

It is a different matter when it comes to property investment that mobilises other channels involving operators that are more varied in character and geographical origin. Let us begin by evaluating its size: according to a DTZ estimate, in 2010, the total value of property assets held by investors in China amounted to US\$1.1 trillion - in second regional position just behind Japan - that is to say, one third of total investment in Asia and almost $10 \%$ of that in the world (Graph 1). Only one third of this amount involves property, while the rest is in debt portfolios. This is not a specific characteristic of China; out of the ten principal countries/regions selected by DTZ in Pacific Asia, seven attract financial capital mainly to property debt rather than to property. ${ }^{(48)}$

On the other hand, China stands apart from other major countries in the region such as Japan and Australia by virtue of its low level of so-called "public" property investment - property that is the subject of stock market transactions. ${ }^{(49)}$ A recent report by JLL estimated at US\$121 billion the overall value of the property held by listed Chinese companies in 2011, out of an overall amount of US\$310 billion. ${ }^{(50)}$ The low level of listed property testifies not only to the low level of internationalisation of the Chinese financial system and the inadequacy of the "institutional" property offer (upper segments), but also to regulatory obstacles to the development of property securitisation. ${ }^{(51)}$

It is therefore mainly in the form of unlisted investment funds that finance capital enters China. Various channels exist depending on the return/risk strategies pursued. To understand the logic at work here, we must remember that investment always presupposes a balance between risk and reward. The greater the risk, the greater the expected return must be, and vice-versa. There follows a classification of the four main categories of the reward/risk trade-off. By order of decreasing risk, we move from an opportunistic logic to "added-value," then "core-plus" and "core" (Graph 2).

Private equity funds most often position themselves in the opportunistic category. Investment groups or banks at the service of large American institutional investors manage the biggest funds. They have their headquarters in the United States and several branches in Asia. Their funds, which have a horizon of four to five years, are only accessible through a share of millions or even tens of millions of US dollars. They work on the principle of mounting major property projects in emerging countries, or most often of acquiring quality assets that have run into problems (badly managed property, debt, or companies in difficulty), restructuring them, and transferring them when the expiry date arrives. Investors must be informed of their "exit strategy," that is to say, to what kind of operators and in what form they intend to transfer their assets. In the case of property portfolios, it is generally core or core-plus funds that take them over with the aim of long-term rental management.

\section{Graph 1 -Value of property and debts held by in- vestors worldwide in 2010 in trillions of dollars}



Source: DTZ Research, Asia Pacific 2011*

* Australia and New Zealand are counted as part of Asia, with 475 million US\$.

Graph 2 - The different risk/return couplings



Veritable closed clubs for the most powerful institutional investors on the planet, these opportunistic funds are cloaked in deep mystery. Only participants have information on the nature and performance of the assets concerned. Their capital is tied up for the entire length of the investment, and there is no secondary market allowing them to resell shares along the way. These funds are nonetheless considered relatively liquid because of their short investment horizon. The rewards are very high, in the order of $20 \%$ or even more. Their attraction for institutional investors such as pension funds, who are nonetheless subject to considerable prudential constraints, is therefore understandable. Faced with a potentially explosive demand for retirement pensions, the latter seek to improve their performance by allocating a small percentage of their capital to high-risk products.

46. Poon, 2010, op. cit.

47. Liu and Zweig, 2011, op. cit.

48. DTZ Research, "Money into Property 2012 Asia Pacific," pp. 5-6.

49. Investment in the stock exchange is said to be "public" because it is accessible to all types of investors, including individuals. As such, it is far more strictly regulated than private investment to prevent small investors who are not property professionals from falling victim to speculative behaviour (see section on REITs further on).

50. JLL, "The Role of Private Equity in Real Estate Markets in Asia Pacific," October 2011, p. 3. This figure includes Chinese groups listed on the Hong Kong stock exchange, who represent the majority. In the case of Japan, the amounts are respectively US\$256 and 581 billion, and in the case of Australia, US\$136 and 177 billion.

51. Two categories of listed property companies exist: property development groups and REIT investment funds. Because of the strict controls on capital in China, Chinese developers chose to launch themselves on the Hong Kong stock exchange (the figure quoted in the text takes the capital of these groups into account). 
Table 1 - Characteristics of indirect property investment in China

\begin{tabular}{|l|l|l|l|}
\hline \multicolumn{2}{|c}{ Property Equity Funds } & Unlisted Property Funds & Listed Property Funds (REITs) \\
\hline Category of funds & Private & Private & Public \\
\hline Type of investor & Big institutional investors & Institutional investors & Institutional investors \& individuals \\
\hline Category of town & Categories 2 and 3 & Categories 1 and 2 & Categories 1 and 1.5 \\
\hline $\begin{array}{l}\text { Origin of } \\
\text { the fund managers }\end{array}$ & $\begin{array}{l}\text { US and Asia-Pacific, } \\
\text { including China }\end{array}$ & $\begin{array}{l}\text { Singapore, Hong Kong, } \\
\text { Australia }\end{array}$ & Singapore, Hong Kong \\
\hline Type of asset & Property, companies, multisectoral & Property, sectoral specialisation & Property, Sectoral specialisation \\
\hline Strategy & Opportunistic & Value-added, core + & Core \\
\hline Return & About 20\% & About 10\% & About 5\% \\
\hline Risk & High & Medium & Low \\
\hline Investment Horizon & 4-5 years & 7-10 years & Long-term \\
\hline Liquidity & Illiquid during the period & Restricted liquidity & Totally liquid \\
\hline Opacity & Very opaque & Opaque & Transparent \\
\hline Volatility & Low & Low & Medium \\
\hline
\end{tabular}

Source: Research by the author

The biggest of these selective fund managers by a wide margin is the New York group Blackstone, world leader in property investment with assets worth a total of US\$49 billion (property and debt). Besides pension funds, this group attracts sovereign wealth funds, financial groups (banks, insurance companies), as well as various public and private institutions - including educational establishments - for whom these alternative investments are part of a strategy of global capital allocation. The most recent fund, Blackstone Real Estate Partner VII, has managed to attract Chinese government money - through $\mathrm{CIC}^{(52)}$ - to the value of US\$3 billion, ${ }^{(53)}$ i.e., $10 \%$ of the amount raised. It goes without saying that this major contribution from the Chinese government has given the American group considerably easier access to land in China.

Blackstone has been present in Asia since 2007. Although it invests in companies in difficulty and in doubtful debt portfolios in India, Australia, and Japan, this is not yet the case in China, where its operations take the form of large-scale development projects. To this end, it has entered into joint ventures with Hong Kong and Chinese developers covering a variety of property sectors including offices, residential accommodation, and logistics. Its projects generally try to take advantage of the new transport infrastructures on the outskirts of Category 2 or 3 cities. For example, its flagship operation is a big business complex in the eastern port zone of Dalian set up in partnership with the Hong Kong group Great Eagle Holdings for a value of US\$630 million. For a group such as Blackstone, all the stages of the property cycle promise high returns: upturns bring capital gains on land in new projects, and downturns offer an occasion to take over the portfolios of operators in difficulty at little cost. The crisis in the Chinese residential sector is, in this respect, a new Eldorado for opportunistic funds. In an ironic twist of fate, funds such as this belonging to American investment banks were eliminated by the subprime mortgage debacle. This was the case with Lehman Brothers and Citibank, as well as for Merrill Lynch, whose holdings in Asia were sold to Blackstone in 2010 for a total value of US\$4.5 billion. ${ }^{(54)}$ Nevertheless, there is no lack of competitors in Asia. The exceptional dynamism of the region attracts big institutional investors. Amongst the thirty biggest managers of property equity funds in the world (those listed by the
PERE 30), (55) eight hold investment "platforms" (56) in Asia, totalling a dozen funds in all. (57) Funds dedicated to a single country are rare, but China is involved in almost all the pan-Asian platforms. The JLL and CBRE groups are to be found once again amongst the big opportunistic equity fund managers. CBRE is noteworthy in particular for its wide range of Asian funds covering all the reward/risk categories. Another world fund manager that has recently established itself in China is Angelo Gordon. This New York operator has managed to acquire vast tracts of land in the biggest Chinese cities (Guangzhou, Shanghai, and Tianjin) on which to mount development operations. Its second opportunistic investment fund in Asia is mainly dedicated to China and covers a wide range of sectors.

Alongside the big managers in the PERE 30 ranking, all but one from the US, ${ }^{(58)}$ certain Asia-Pacific operators also manage opportunistic funds in the region. Two Australian groups, Macquarie and Goodman, have created a Hong Kong-based joint venture, "Macquarie Goodman Asia," to develop a fund specialising in industrial property in China. The Singapore groups CapitaLand and ARA use opportunistic funds as incubators ("CapitaMall Development" and "CapitaMall incubator" for CapitaLand, and "Asia Dragon Fund" for ARA) in order to build property portfolios that they then transfer to their other core or value-added funds (unlisted funds or REITs, see below).

However, the most involved in opportunistic investment in China is the

52. China Investment Corporation (CIC) is a public company founded in 2007 to invest China's US\$70 billion foreign reserves abroad. Its first move was to invest US\$3 billion in Blackstone's private equity fund.

53. Asia Times, 2 September 2007

54. Merrill Lynch has fallen back on North America and Europe. Its holdings in Asia included an opportunistic property fund of US\$2.7 billion and a US\$1.8 billion balance-sheet portfolio.

55. Private Equity Real Estate. The PERE 30 ranks managers in order of the amount of capital raised during the period 2007-2012. Source: PERE 30 "PERE's ranking of the 30 largest private equity real estate firms in the world," May 2011.

56. Series of funds.

57. The eight managers of the PERE 30 operating in China are Blackstone (world, multisectoral) Tishman Speyer (China, residential), JLL (Asia, multisectoral), MGPA (Asia, commercial), CBRE (Asia multisectoral, China multisectoral), Angelo Gordon (Asia, multisectoral), AEW Global, Hines (ChinaRussia multisectoral, China industrial and hostelry). Source: The managers' Internet sites.

58. The only manager in the PERE 30 not to have a head office in the United States is MGPA, based in London and Singapore. 
Table 2 - Main sponsor groups of property investment funds holding property in China

\begin{tabular}{|c|c|c|c|c|c|}
\hline $\begin{array}{l}\text { Categories } \\
\text { of funds }\end{array}$ & $\begin{array}{l}\text { US Funds (PERE 30), } \\
\text { groups sponsors }\end{array}$ & $\begin{array}{l}\text { Singaporean } \\
\text { Funds }\end{array}$ & $\begin{array}{l}\text { Hong Kong } \\
\text { Funds }\end{array}$ & $\begin{array}{l}\text { Australian } \\
\text { Funds }\end{array}$ & $\begin{array}{l}\text { Chinese } \\
\text { Funds }\end{array}$ \\
\hline Opportunistic Funds & $\begin{array}{l}\text { Blackstone } \\
\text { Lassalle (JLL) } \\
\text { CBRE } \\
\text { Angelo Gordon } \\
\text { Hines Int'l } \\
\text { AEW Global }\end{array}$ & Capitaland & Cheung Kong (ARA) & Macquarie & $\begin{array}{l}\text { China Resource } \\
\text { (Harvest Capital) }\end{array}$ \\
\hline Value-added funds & CBRE & $\begin{array}{l}\text { Keppel Land } \\
\text { (closed Funds) } \\
\text { Capitaland } \\
\text { Ascendas }\end{array}$ & Cheung Kong (ARA) & & \\
\hline Core + funds & CBRE & $\begin{array}{l}\text { Capitaland } \\
\text { Ascendas } \\
\text { Pacific Star }\end{array}$ & Cheung Kong (ARA) & & \\
\hline REITs & & Ascendas & Cheung Kong (ARA) & & $\begin{array}{l}\text { Yue Xiu (listed in } \\
\text { Hong Kong) }\end{array}$ \\
\hline
\end{tabular}

Source: Research by the author

fund manager Harvest Capital, a subsidiary held entirely by the prominent Chinese conglomerate China Resources Group. Harvest Capital manages four opportunistic funds exclusively centred on China - including one dedicated to Muslim investors ${ }^{(59)}$ - totalling US\$1.38 billion, $80 \%$ of whose unit-holders live outside the country. Here again, a multisectoral strategy is being pursued, limited to the biggest urban agglomerations. Thanks to the privileged relationships it has with the Chinese authorities, Harvest Capital has performed better than its foreign competitors, showing a rate of return of 30\% in a little more than a year between 2010 and 2011 for the acquisition of four portfolios of shopping malls. ${ }^{(60)}$

\section{Unlisted property funds and REITS}

As soon as one moves to a less risky category of investment of the valueadded, core-plus, or core type, a clear change in the composition of the asset portfolios can be observed. They become more specialised, made up exclusively of property (series of buildings or parts of buildings) anchored in well-defined sectors (residential, offices, shops) but often pan-Asian in scope. Apart from a few exceptions (CBRE, Macquarie), the managers of these funds are affiliated with the big Singapore groups and to a lesser degree with Hong Kong groups, and benefit from privileged relationships with the Chinese authorities. However, there are important differences between property funds, depending on whether or not they are listed (Table 1).

Unlisted funds are intended for institutional investors of all sizes as well as for wealthy individuals able to make an initial payment of around half a million US dollars. It is no longer a question here of benefiting from a windfall effect by taking risk, but of investing one's capital in asset portfolios that offer good returns and that are held in the medium and long-term. The same performances are expected from these unlisted funds as from direct investment in property without having to invest large amounts of capital. Amongst the measured risk investments, direct property is the one where performance is the least correlated with that of other financial assets. It can therefore improve the overall performance of portfolios made up of a variety of categories of asset. However, it also ties up the heaviest capital investment, which is why investors now tend to avoid it in favour of units in in- vestment funds. These unlisted property funds are nonetheless just as opaque and have the same low liquidity as the equity funds, since shares are often only transferable after several years, provided a taker can be found. However, institutional investors are increasingly searching for liquidity. ${ }^{(61)}$ This is due to several factors, including the increasing gap between the evolution of the life cycles and the maturity of the savings instruments of the pension funds, ${ }^{(62)}$ and the need to arbitrate permanently between the various financial instruments to improve performance.

For these reasons, listed property funds developed in Asia from the early 2000s onwards. Known as REITs (Real Estate Investment Trusts), they are accessible to all types of investors, and as stock negotiable every day on the stock exchange they have a high level of liquidity. The introduction of REITs into a country calls for the adoption of complex and restrictive legislation, the issue being to prevent small savers from falling victim to speculation. The performance of portfolios must be published regularly, considerably increasing the transparency of the funds. These are all the more attractive given that investors receive dividends each year and can benefit from tax advantages under certain conditions.

REITs belong to the core category because their property portfolios present the least risk: high-quality buildings, long-term (non-speculative) investment, and central locations in top-category towns. Like unlisted funds, they specialise in a variety of property sectors so as to allow investors to arbitrate in accordance with the risk/return profiles and specific dynamics of the various industrial sectors. Only residential property is not represented in REIT funds (63) - except in the form of serviced apartments that count as hospitality - on account of the high cost of managing the buildings, which erodes returns.

59. This is the "Al-Rhaji China Real Estate Growth Fund" worth US\$500 million.

60. Property Investor of the year, The Asset Magazine, www.harvestcapital.com.hk/en/index.php (accessed on 9 December 2012).

61. José Corpataux, Olivier Crevoisier, "Increased Capital Mobility/Liquidity and its Repercussions at Regional Level: Some Lessons from the Experiences of Switzerland and UK," European and Urban Regional Studies, Vol. 4, No. 12, 2005, pp. 315-334.

62. Ewald Engelen, "The Logic of Funding European Pension Restructuring and the Dangers of Financialisation," Environment and Planning A, Vol. 35, 2003, pp. 1357-1372.

63. REIT funds rarely invest in residential property. Japan and the United States are exceptions in this respect. 
Although REITs offer this much sought-after liquidity, they present the lowest returns and are more volatile than the others since they are the object of daily transactions. Consequently, there is a lesser degree of decorrelation with other financial products than in the case of unlisted funds. However, many institutional investors favour this stock for the satisfactory compromise it offers between real estate company shares that are too volatile and unlisted property with weak liquidity. Others choose exposure on the two property fund categories, listed and unlisted, considering them to complement one another.

Four big regional groups operate in China with unlisted property funds and REITs: CapitaLand, Mapletree, Keppel Land, and ARA.

The CapitaLand conglomerate is the leading foreign operator on the Chinese continent, with 120 projects in 40 cities. The major part of its portfolio is composed of direct property investment, developed by two of its subsidiaries, CapitaMalls Asia (commercial property) and CapitaLand China Holdings (other property sectors). The group also manages several investment funds covering all risk categories, however. One of them is specifically in charge of five "Raffle City" operations out of the seven developed by CapitaLand. These big multifunctional self-contained complexes, often with a surface area of more than 200,000 square metres, are designed as "cities within a city." Implanted in the biggest Chinese agglomerations, they are significant markers of urban identity, and purveyors of "quality of life and business value." Each complex has a unique design, the work of a wellknown international architect. The projects are therefore extremely varied, but CapitaLand's property sectors are represented everywhere: offices, retail, serviced apartments, and hotels. Besides the five "Raffle City" operations portfolio, the subsidiary CapitaLand Financial manages an unlisted property fund - the product of one of its opportunistic funds - as well as two REIT funds. One is dedicated specifically to China and is made up of nine big shopping malls, including four in Beijing, and the other, managed by its hotel property subsidiary (also in charge of the serviced apartments), is pan-Asian in scope and made up of four hotels in Category 1 towns.

Another big Singapore group, Mapletree, is also very involved in direct property investment in China, specialising in the development of technology parks. It invests through an unlisted fund and a REIT fund. The first, opportunistic/value-added in nature, favours Asia's emerging countries ("Mapletree India China Fund") and includes five big urban complexes in China (equivalent to the "Raffle Cities") in Category 1 and 2 cities. Its REIT fund specialises in logistics (Mapletree Logistic Trust). It manages more than one hundred properties, including six warehouses in China, most of them in Shanghai.

Amongst the main Singaporean property operators, the Keppel Land Group is the least present in China. Its subsidiary Alpha Investment Partners manages a fund that holds several big residential and commercial properties and hotels in China's major urban centres.

Unlike the preceding groups, ARA Asset Management is purely a fund manager. Listed on the Singapore stock exchange, it is in reality affiliated with the Hong Kong property conglomerate Cheung Kong, whose director is the tycoon Li Ka-shing, possessor of the biggest fortune in Asia and ninth largest fortune in the world. ${ }^{(64)}$ With its 16 funds, ARA is the only Asian manager to come close to the PERE 30 rankings. Amongst the five REITs that it manages, Hui Xian, listed on the Hong Kong stock exchange, is the only foreign REIT entirely devoted to China, and what's more, in RMB so that investors can benefit from the internationalisation of China's currency. ${ }^{(65)}$ Unlike other REITs that try to limit risk by spreading their properties over a large number of sites, Hui Xian concentrates its asset portfolio in just two places: the centre of Beijing with the "Oriental Plaza" complex (several office blocks, serviced apartments, shopping malls, and a hotel), and in Shenyang with the Sheraton Lido Hotel. In both cases, ownership of the land and buildings, estimated at US\$5.2 billion ${ }^{(66)}$ at the end of 2011, belongs to a local Chinese operator in JV with the ARA group. This atypical concentration on just two sites can be explained by the tightening up of regulations concerning foreign investment in securitised real estate since the subprime mortgage crisis, which penalised the acquisition of new properties by REIT funds.

The excellent performance recorded by the various investment funds will attract an increasing amount of finance capital to China over the next few years. The overall value of institutional property in the country, currently standing at US\$1,900 billion (7\% of the global value) could, in some estimates, reach US\$9,700 billion in the course of the next decade. ${ }^{(67)}$ Not only will increasing numbers of institutional investors from Western industrialised countries want a share of this maturing market (those from the United States taking up a position in Asia currently represent 47\%, and those from Europe 34\%), (68) but their Asian counterparts will become more powerful and also wish to increase their share.

Despite all this, the road ahead is not without obstacles. The experience of recent years shows that finance capital does not always find investment for lack of a big enough offer in the higher segments of the property sector. According to an estimate by JLL, out of the US\$22 billion raised abroad by private funds between 2007 and 2010 for allocation in China (equity funds or unlisted property funds), only $\$ 9.2$ billion were used in a transaction at the end of the period. ${ }^{(69)}$ The Chinese authorities therefore tried to accelerate the production of institutional property by stimulating the activities of Chinese developers. National property champions were already emerging. Groups such as Vanke, Evergrande, Poly Real Estate, and Wanda showed their capacity to rival Hong Kong and Singaporean developers, but their expansion was curbed by difficulties in obtaining credit from national banks. As far as possible, therefore, they had to fall back on financial capital.

For the time being, the launching of REITs is still blocked by the inadequacies of the tax system and the fragmentation of the administrative authorities in question. Several Chinese developers have tried to find a way round this by launching securitised funds on the Hong Kong stock exchange, but only one has succeeded - the Yue Xiu property group. Formerly a stateowned company, this Cantonese group created the GZI REIT, to which it transferred a set of six office buildings and shopping malls in Guangzhou. To date it is the only REIT held by a Chinese company on the mainland, but it is not inconceivable that local regulations will soon be set up in the largest cities, beginning with Shanghai, to launch experiments in property securitisation (Table 2).

64. Forbes, "The World's Billionaires," 2012.

65. Michel Aglietta, "Internationalisation de la monnaie chinoise" (Internationalisation of Chinese currency), Perspectives Chinoises, No. 3, 2011, pp. 84-88.

66. Value in December 2011, exchange rate in December 2012

67. According to a high hypothesis estimate by APREA, a think-tank that brings together Asia-Pacific investment funds. Source: APREA, "The Benefit of an Allocation to Asian Real Estate for Institutional Investors," November 2011, p. 39.

68. APREA, ibid., p. 40.

69. Jones Lang LaSalle, "The Role of Private Equity in Real Estate Markets in Asia Pacific," October 2011, p. 3. 


\section{Conclusion}

With the expansion of financial capital into urban production, a new map of China is being drawn. Unlike geographers, who observe the emergence of urban clusters along major transport routes, foreign investors have a more fragmented view, bound by the limits of the municipal authorities with whom access to land resources and the rules of construction are negotiated. Their interpretation serves as a support for stratification of investment funds according to return/risk profiles, with short-horizon opportunistic funds venturing out onto pioneer fronts and pushing westwards, whilst long-term investment strengthens the existing markets in the centres of the agglomerations as they mature.

The division of national space in the service of property investment has been drawn up by international consultancies established locally, whose capacities for monitoring local property and supporting foreign investors is increasing as they extend their services to Chinese companies. These players play a vital role in facilitating the anchorage of financial capital from North American funds - in the institutional form of the JV - many of which are aiming at short-term strategies with high returns (opportunistic funds). It is a different matter for funds managed by regional players that are generally aimed at the longer-term (value added or core-plus), which benefit from guanxi maintained over a long period with the authorities in mainland China and so more easily resolve the problem of access to land resources. Although some of these funds fall into the opportunistic range, they are generally designed as the trigger for longer-term investment.

The penetration of financial capital into urban areas tends to exacerbate fragmentation and the functional specialisation of neighbourhoods superimposed on the heterogeneous cellular morphology of the Maoist city. This process of spatial differentiation is encouraged by public entrepreneurial strategies that pursue financial revenues and prestige at the local level. As a result, urban projects are becoming standardised both in terms of design and program, governed by external references that favour the expansion of multinationals and transform lifestyles and consumer habits.

Although the financialisation of the Chinese property sector has involved channels dominated by foreign groups, national operators have already begun to enter the sector successfully, as the excellent performance of the Harvest Capital Group's opportunistic funds show. Since the institutional property pool is under-developed in China, prospects for the expansion of financial capital in this sector are immense. As the property markets gain in maturity, the number of managers of foreign funds will increase, but they could soon be confronted with the rising power of national competitors made even more formidable by the persistence of the dual land market and regulatory obstacles. Whatever balances result from this, the Chinese property sector will unquestionably attract increasing institutional investment flows from abroad, notably from pension funds, attracting the savings of ageing Western and Eastern societies.

I Translated by Elizabeth Guill.

Natacha Aveline-Dubach is CNRS Research Director, Laboratoire Géographie-Cités, University of Paris 1/Paris 7.

University of Paris 1/Paris 7, 13 rue du Four, 75006 Paris

(aveline@jp.cnrs.fr). 